IX. On additional Bones of the Dodo and other Extinct Birds of Mauritius obtained by Mr. Théodore Sauzier. By Sir Edward Newton, K.C.M.G., F.L.S., C.M.Z.S., and Hans Gadow, Ph.D., M.A., F.R.S., F.Z.S.

Received October 31st, 1892, read November 1st, 1892.

\title{
[Plates XXXIII.-XXXVII.]
}

IN 1889 the Government of Mauritius appointed a Commission to enquire into the "Souvenirs Historiques" of that island; and in furtherance of their object, at the instance and under the able direction of their President, Mr. Théodore Sauzier, they continued the exploration of the Mare aux Songes-the marsh in which the late Mr. George Clark, upwards of five-and-twenty years ago, made the discovery of a vast deposit of bones of the Dodo ${ }^{1}$ and other animals, mostly now extinct, and the only locality in Mauritius where remains of the Dodo have been found in any quantity ${ }^{2}$.

This exploration has been very successful, for not only have many Dodos' bones, some of them new and others represented only by imperfect specimens, been recovered, but also a considerable number of the bones of other birds, materially adding to our knowledge of those which had been but partially described, and proving the former existence in Mauritius of species either vaguely indicated by old voyagers or wholly unsuspected to have been members of its fauna. Besides these there have been found many remains of the large extinct Lizard, Didosaurus mauritianus ${ }^{3}$, and several carapaces, more or less entire, though none absolutely perfect, belonging to one or other of the extirpated 'Tortoises.

Nearly the whole of these specimens have been sent by Mr. Sauzier, on behalf of the Commission over which he presided, to the Museum at Cambridge, with a view to their determination and to the description of such as are new, and this task has been undertaken by the present writers.

Before proceeding to its execution, it may be as well to recall the fact that up to the present time, beside bones of Didus ineptus, those of the following birds have been obtained from this marsh and described as under :-

Lophopsittacus mauritianus (Owen). Lower Jaw. R. Owen, Ibis, 1866, pp. 168 et seqq.

Tibia. A. Milne-Edwards, Ann. Sc. Nat. sér. 5, vi. pp. 91 et seqq. (1866).

\footnotetext{
${ }^{1}$ Ibis, 1866, pp. 141 et seqq. $\quad$ ' Proceedings of the Zoological Society, 1890, pp. 402 et seqq.

${ }^{3}$ Günther, Journal of the Linnean Society, Zoology, xiii. pp. 322 et seqq.

vol. XIII.-PART vir. No. 1.-August, 1893.

2 T
} 
Astur, sp. indet.

Ardea garzetta, Linnæus.

Aphanapteryx broecki (Schlegel).

Fulica newtoni, A. Milne-Edwards.
Metatarsus. Id. op. cit. xix. art. 3 (1874).

Tibia. Id. loc. cit.

Lower Jaw, Tibia, Metatarsus. Id. op. cit. x. pp. 325 et seqq. (1868).

Pelvis, Tibia, Metatarsus. Id. op. cit. viii. pp. 195 et seqq. (1867).

All these are species which no longer occur in the island.

Bones of a species of Phoenicopterus have also been found (G. Clark, Ibis, 1866, p. 144, and A. Milne-Edwards, Ann. Sc. Nat. sér. 5, xix. art. 3).

The present collection contains not only bones of the above-named birds, but also those of a Finch (?), an Owl, four other species of Heron, a Bittern, a Darter, a Gannet, a Goose, a Duck, a Grebe, two species of Pigeon, one of which is probably the extinct Funingus (Alectorønas) nitidissimus, a Water-hen, and two Petrels, of which we proceed to describe and characterize as new :-

\section{Strix sauzieri, Astur alphonsi, \\ Butorides mauritianus, Plotus nanus, Sarcidiornis mauritianus, and Anas theodori.}

In naming these species we wish by the first and last to commemorate the services to science of Mr. Sauzier; while the Astur, being in all probability identical with that recognized but left unnamed by Professor Milne-Edwards, may be appropriately dedicated to him.

Of birds previously distinguished we have now for the first time the following parts :-

Didus ineptus.-Atlas, Prepelvic or "intermediate"(18th) Vertebra, complete Pubic Bones, and Metacarpals.

Lophopsittacus mauritianus. - Sternum (?), Femur, Metatarsus, beside Lower Jaw far larger than that first described.

Aphanapteryx broecki. - Upper Jaw, third Cervical Vertebra, Pelvis, Humerus, Femur ${ }^{1}$.

Fulica newtoni.-Cervical vertebræ (third and ninth or tenth), Sternum, Sacrum, Humerus, Ulna, and Femur ${ }^{1}$.

1 There is a large series of tibiæ (39 right and 50 left), which must belong to one or the other of these two species, but except in a few cases it is impossible to distinguish between them. 
One specimen at least of each of the bones now first described has been kindly presented by Mr. Sauzier, on behalf of the Commission of which he is President, to the Museum of the University of Cambridge, as well as a series of other bones in proportion to the extent of the collection. The remainder, including a magnificent skeleton, which has been mounted in that Museum and is doubtless the most complete in the world, of Didus ineptus, will be ultimately deposited in the Museum of Mauritius at Port Louis.

\section{Lophopsittacus mauritianus. (Plate XXXIII. figs. 1-8.)}

A complete tibia obtained previously from Mauritius and having been assigned, although not described, by M. Milne-Edwards to Lophopsittacus mauritianus, made it easy to recognize 46 other tibiæ taken from the Mare aux Songes as belonging to the same species of Parrot.

Several femora, varying from 58 to $63 \mathrm{~mm}$. in length, are likewise easily referable to the same species.

There is also a left tarso-metatarsus of $35 \mathrm{~mm}$. in length, typically flattened and broadened out, with the outer condyle turned backwards and outwards in accordance with the reversed fourth toe. The plantar tuberculum near the proximal end of the bone is partly broken off, but sufficiently preserved to show the two canals lying side by side, through which the tendons of the deep flexors of the hallux and other three digits passed. Near the inner or tibial margin of the second metatarsal is a deep impression, caused by the insertion of the tendon of the $\mathrm{m}$. tibialis anticus. The position of this insertion, near the inner side of the second metatarsal, instead of near the middle of the third metatarsal, is typical of Parrots. Above this impression is a deep oblique groove, in which lodged the tendon of the m. extensor digitorum in its oblique course from under the bony tibial bridge to the inner side of the foot. This peculiar groove exists also in Necropsittacus rodericanus, Calyptorhynchus funereus, Cacatua galerita, Licmetis tenuirostris, and Macrocercus macao, but apparently not in Stringops, Domicella, or Trichoglossus, although the tendons run in precisely the same direction, passing over the tarsus without leaving any impression upon the bone. The erratic occurrence of this groove, intensified by age, but absent in a fully adult Stringops, detracts from its taxonomic value.

The following measurements show that the relative lengths of the femur, tibia, and metatarsus from Mauritius are so similar to those of other Old-World Parrots that the bones in question can without doubt be referred to one species only. The measurements show also that this species was considerably larger than Necropsittacus rodericanus, agreeing in the length of its hinder extremity with Cacatua galerita. 


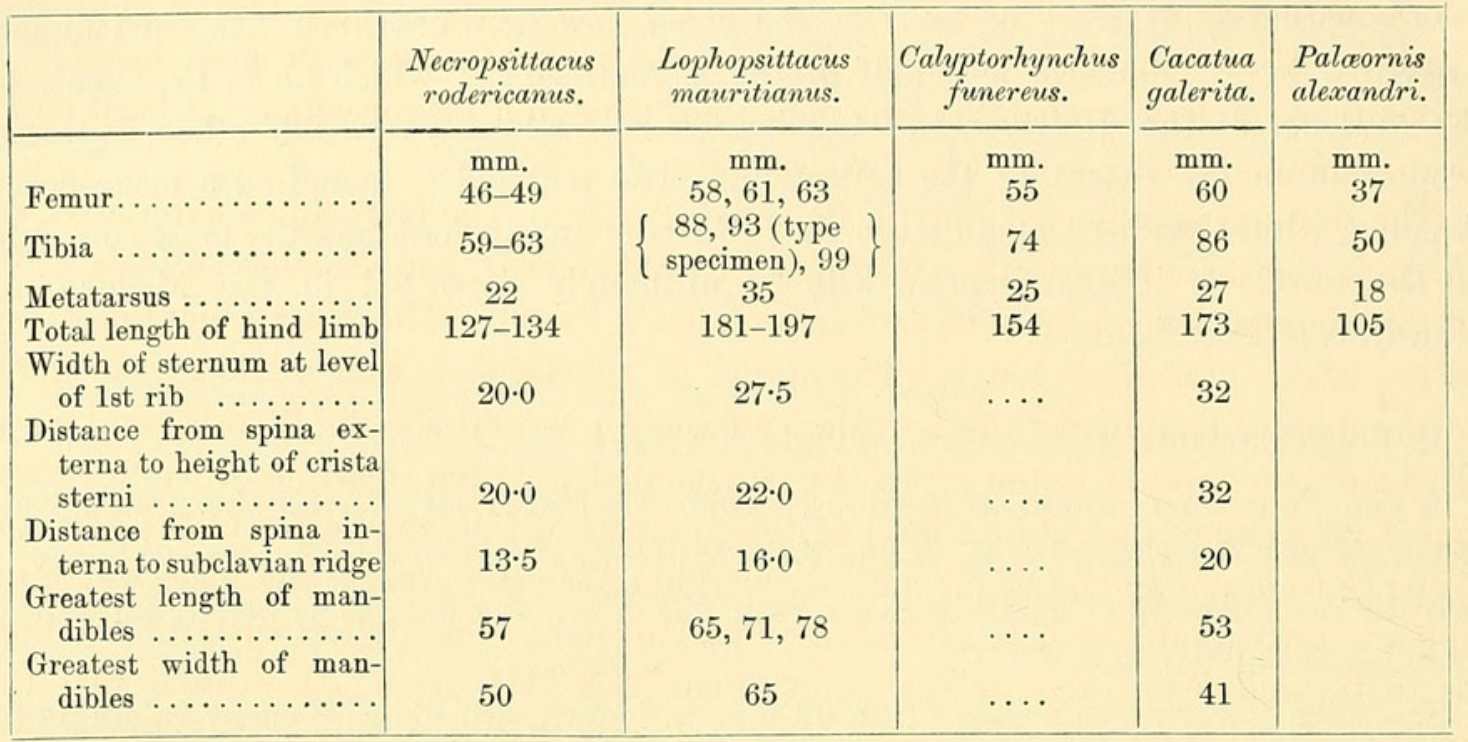

The most interesting part of this Parrot is the enormous underjaw. One pair of underjaws is absolutely complete but for a few particles of bone being broken off from the anterior margin. The left mandibles of two other specimens are nearly complete. A fourth specimen is represented by the posterior half of the left mandible only. These four jaws vary somewhat in size. The distance from the posterior angle ( $p$ in fig. 5, Plate XXXIII.) to the anterior end of the complete symphysis is in the largest and best preserved specimen $78 \mathrm{~mm}$., in the next 71, in the third only $65 \mathrm{~mm}$. The smallest specimen of the extinct Mauritian Parrot is consequently still $8 \mathrm{~mm}$. larger than that of Necropsittacus rodericanus. The width of the mandibles shows the same proportions. Each underjaw has a distinct additional articulating facet, about $7 \mathrm{~mm}$. in length, for the ventral surface of the outer process of the quadrate, which carries the jugal bone. Such an additional facet, besides the usual one at the ventral end of the quadrate, is indicated in Cacatua galerita, broad and well developed in Stringops, Calyptorhynchus, and Ara: in fact, in many Parrots with powerful and broad underjaws.

It seems rather improbable that such an enormous jaw should be associated with a Cockatoo of moderate size; but, curiously enough, the comparison of the greatest length of the mandibles with the total length of the hinder extremity shows that Necropsittacus rodericanus had actually a proportionately larger jaw than the species of Mauritius, because the length of the jaw should not be more than 50 or $\tilde{j}$, while it is in fact $57 \mathrm{~mm}$. Of course it is hardly necessary to observe that there can scarcely be any correlation between the length of the whole leg and the size of the bill and head in a Parrot; but, having to deal with scanty remains of birds whose anatomical structure is otherwise unknown, we have to be grateful for small mercies. At any rate, we find that the Parrots from Mauritius and from Rodriguez not only resemble each other in the proportions of the bones of their hinder extremities, but also in the 
enormous development of their jaws, a feature which makes them unlike any other Parrots. Moreover, these considerations enable us to discuss with some amount of certainty, or at least probability, the only other bone of a Parrot which has been found in the Mare aux Songes: to wit, the sternum.

The sternum is preserved only in its anterior part. The large spina externa agrees in shape and direction exactly with that of $N$. rodericanus, and excludes any possibility of this sternum belonging to any other bird but a Parrot. The ventral margin of part of the keel is broken off, but the line of the m. subclavius is well marked; the whole of the anterior margin and the articulating facets for several ribs are likewise uninjured. This sternum appears at the first glance undoubtedly far too small for L. mauritianus, but if we measure its width in level of the first pair of ribs, the height of the keel, the distance from the middle of the anterior margin of the sternum (at the place where the spina interna would be if it existed in these Parrots) to the highest curve of the keel, or to the muscular ridge at the point (Plate XXXIII. fig. $7, S$ ), we find that this fragmentary sternum by all its dimensions indicates that it belonged to a larger bird than $N$. rodericanus. In fact, the size of this sternum would fit one of the smaller specimens of L. mauritianus; and this is corroborated by the following calculation, which gives a result which we should not have expected:-Average of total length of hind limb of $N$. rodericanus $(130)$ : width of its sternum $(20)=$ Length of hind limb of smallest $L$. mauritianus (181): width of its sternum would be $27 \cdot 8$, while our single sternum from Mauritius actually measures $27.5 \mathrm{~mm}$. across!

There can be no doubt that the extinct Mauritian Parrot was a larger but otherwise nearly allied form of the Parrot from Rodriguez; it is, however, questionable whether both might not be included in the same genus Necropsittacus, for while we know from old drawings that the Mauritian form had a sort of ornamental crest, we know nothing to the contrary of $N$. rodericanus.

2. Astur alphonsi, sp. nov. (Plate XXXIII. figs. 9, 10.)

Amongst numerous Asturine remains a pair of tibiæ, a pair of metatarsals, and the metacarpals of the left side are probably referable to one individual bird of prey. The two metatarsals, with a length of $81 \mathrm{~mm}$., agree perfectly with that figured by M. Milne-Edwards (plate 33. fig. 2). He rightly referred them to the genus Astur, and remarked that they belonged to a bird which was undescribed and unknown, unless it was identical with $A$. melanoleucus from the Cape of Good Hope. We have been able to measure the length of the tarso-metatarsus of an $A$. melanoleucus, and have found that it agrees in this respect with the two bones in question. It would therefore seem reasonable to assign these bones to A. melanoleucus, unless the absence of this SouthAfrican species from Madagascar, and the numerous instances of insular forms or species of Hawks, be deemed arguments sufficiently strong to distinguish the bird to which these bones belonged as Astur alphonsi. 
The greatest length of the two tibiæ is $117 \mathrm{~mm}$., which agrees proportionately with that of the two metatarsi, so as to justify us in connecting them with each other as those of the same Hawk, a view which is corroborated by the tibial and metatarsal articulating facets fitting well upon each other. The bony bridge for the $\mathrm{m}$. flexor digitorum communis is very strong, the fibula reaches far down the tibia, the peroneal crest is straight and long, the cnemial crest slants gradually into the anterior inner edge of the shaft of the tibia.

It is of course impossible to state with certainty whether the metacarpal bones, the total length of which is $55 \mathrm{~mm}$., belong to the same individual ; that they belong to the same species is more than probable, and that they are those of a diurnal bird of prey of the size of Astur melanoleucus is unquestionable. All the facets, tendinous impressions and processes, and the sharp, blade-like, deeply scooped-out third metacarpal bone mark the specimen.

3. Strix sauzieri, sp. nov. (Plate XXXIII. figs. 11-18.)

The Owls are generally classified according to cranial, sternal, and various purely external characters. None of these points will serve our purpose, because the only bones of Owls in the present collection are those of the humerus, tibia, and metatarsus.

There is one character, namely the relative length of the tibia to that of the metatarsus, which is not only very constant but also very characteristic of the various families and even genera of Owls. From the quotient resulting from the division of the length of the tibia by that of the metatarsus we have come to the conclusion that the majority of the bones in question, namely four metatarsals, three tibiæ, and, by inference, two humeri, belonged to a member of the long-footed Owls, of which Strix flammea and its allies is the most pronounced type, while Heliodilus soumagnii from Madagascar closely approaches it, to the exclusion of Carine murivora from Rodriguez, Scops, Sceloglaux nova-zealandia, Spiloglaux, Gymnoscops, Asio, and Bubo as examples of the several subfamilies and principal genera of the so-called Bubonida.

We have much pleasure in distinguishing this new Owl from Mauritius as Strix sauzieri, referring it to the genus Strix, and not to Heliodilus, on the strength of most of those very characters which induced M. A. Milne-Edwards to establish the new genus Heliodilus ${ }^{1}$. These characters are, first, the relative length of the tibia

${ }_{1}$ It will be convenient to mention here at least those characters which could be tested with the material at our disposal :-

“L'Héliodile est un Strigide à pattes robustes, à ailes plus courtes et à tête plus large que les Effraies( Strix). Le tibia est plus long et les proportions en sont différentes, car l'extrémité inférieure est plus robuste et le corps de l'os est aussi grêle; la crête péronnière est courte et le péroné ne se prolonge pas autant que chez les Chouettes et les Hibonx. Si l'os de la jambe est plus long que celui de l'Effraie, celui du pied est au contraire plus court; mais ses caractères sont à peu près les mêmes que dans ce dernier genre."-A. Milne-Edwards, Comptes Rendus (1878), vol. 85, p. 1282. 
and metatarsus; secondly, the length of the "péroné" or fibula, which, at least in the two larger specimens, is continued far beyond the level of the tubercle of the hallux attachment, as far down as the epicondyle; thirdly, the relatively greater length of the peroneal crest, which in our specimens extends to the end of the upper third of the tibia, while in Heliodilus it ends a little below the upper fourth; the actual peroneal connexion, $i$. e. the ridge of the tibia which touches the fibula, is absolutely and relatively larger in our specimens than on the tibia figured by M. Milne-Edwards (Grandidier, Ois. de Madagascar, plate $36 c$, fig. 8).

On the other hand, there are differences, notably the longer and higher cnemial process of the tibia and the shortness of the humerus, sufficient to justify the specific distinction of this Mauritian Owl from Strix flammea, with its numerous varieties.

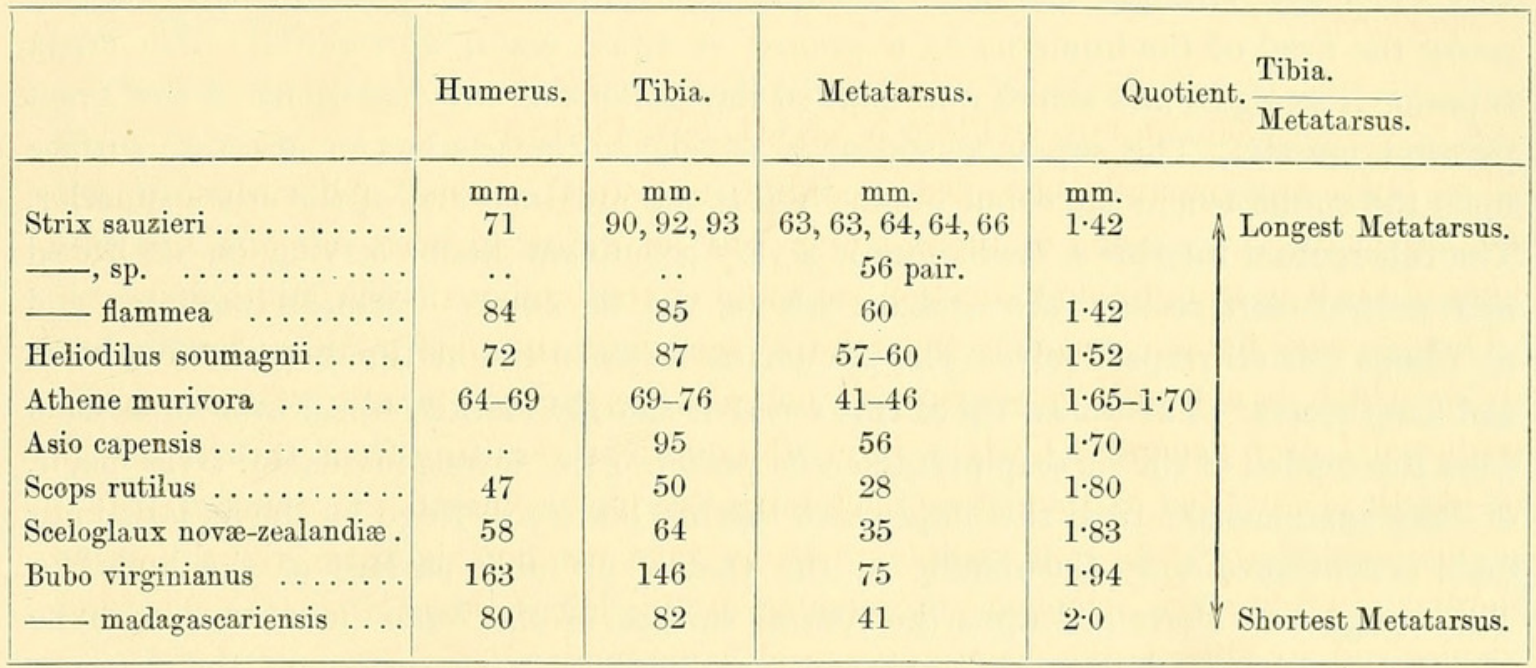

The pair of metatarsi measuring $56 \mathrm{~mm}$. in length are at the same time much more slender than the other five metatarsi. We do not feel justified in explaining this considerable difference in size and strength by difference of age, because the bones are fully ossified and show all the characteristic markings in the same pronounced degree. Only the bony bridge over the tendon of the $\mathrm{m}$. tibialis anticus is broken, and was moreover certainly incomplete in both of the smaller metatarsi. We naturally tried to fit the shortest tibia of $90 \mathrm{~mm}$. length on to the metatarsus of the corresponding side, but the tibial condylar facets are a little too large. If they fitted, the quotient of this shortest tibia with the shortest metatarsus being $1 \cdot 61$ would indicate an Owl different from any of those which are mentioned in our list. Asio capensis cannot be thought of, because its metatarsus is several times stronger than the two in question, nor do we feel inclined to explain the shortness and slender shape of these two bones by sexual difference of Strix sauzieri. Unless we assume, what is unlikely, that the island of Mauritius possessed two different species of Strix, we have to conclude that the short pair of metatarsals belonged to a small individual of Strix 
sauzieri, although it is rather improbable that this species, restricted to a small island, varied as much as British specimens of Strix flammea, of which latter the British Museum Catalogue records the length of the "tarsus" as 2.2 inches, i. e. $55 \mathrm{~mm}$., while the measurements taken from an English specimen in the Cambridge Museum give the length of this bone as $60 \mathrm{~mm}$.

\section{Plotus nanus, sp. nov. (Plate XXXIV. figs. 1-5.)}

The humerus, pelvis with sacrum, and tibia of the genus Plotus possess so many diagnostic characters that the three bones figured on Plate XXXIV. can easily be recognized as belonging to this genus of Steganopodes.

The Humerus shows the following characteristic points:-The sulcus transversus is very deep and strongly marked, extending from the tuberculum mediale halfway across the head of the humerus as a groove of equal width and depth. The crista superior is straight, and shows well-marked impressions of the insertions of the great pectoral muscle. The supracoracoidean or subclavian muscle has an inserting surface upon the corner where the caput humeri meets the proximal end of the crista superior. The tuberculum inferius s. medianum is a very prominent knob, serving on its dorsal and ventral surfaces for the attachments of the m. coraco-brachialis posterior and $\mathrm{m}$. biceps humeri respectively. The pneumatic foramen lies at the bottom of a wide and deep recess. The dorsal lip of this recess is sharply marked by an oval impression from the tendon of the $\mathrm{m}$. scapuli-humeralis posterior $(\mathrm{m}$. infraspinatus, $\mathrm{m}$. teres major, of other anatomists); from this impression the low but sharp ridge for the $\mathrm{m}$. latissimus dorsi is continued down the middle of the ventral or inner surface of the humerus. The two grooves above and upon the ventral surface of the outer and inner condyles are produced by the origins of the pronator and short flexor muscles of the forearm. The $\mathrm{m}$. brachialis inferior s. internus arises from a strongly marked impression on the dorsal or outer surface of the distal part of the shaft of the humerus.

The Pelvis and Sacrum are easily referred to the genus Plotus by the deeply notched or curved lateral margin of the pre-acetabular part of the ilium, the prominent and sharp antitrochanter, the sharp ventral ridge springing from the three anterior sacral vertebræ, and by the position of the single primary sacral vertebra closely behind the acetabular axis. The individual peculiarity of the specimen described is the lopsided position of the two halves of the pelvis with reference to the sacrum.

The Tibia is much flattened anteriorly; its anterior or cnemial crests are high, but not anchylosed with the patella; the peroneal crest for the attachment of the fibula is long and straight. The condylar portion of the tibia is turned considerably inwards, and the bridged-over groove for the passage of the tendon of the m. extensor digitorum communis is very deep and placed obliquely.

There remains the question of the specific differences of the bones before us. They all belong, to judge from their appearance, to one adult individual, but their small 
size excludes at once the possibility of their being referable to any of the species hitherto known, as the following measurements will show. We distinguish it, on account of its small size, as Plotus nanus.

\begin{tabular}{|c|c|c|c|c|}
\hline Left humerus & $\begin{array}{l}\text { Plotus nanus. } \\
\text { mm. } \\
89\end{array}$ & $\begin{array}{c}\text { P. anhinga. } \\
\text { mm. } \\
112\end{array}$ & $\begin{array}{l}\text { P. melanogaster. } \\
\text { mm. } \\
132\end{array}$ & $\begin{array}{c}\text { P. nov.-holland. } \\
\text { mm. } \\
120\end{array}$ \\
\hline Left tibia $\ldots \ldots \ldots \ldots \ldots \ldots \ldots$ & 61 & 77 & 86 & $78-95$ \\
\hline $\begin{array}{l}\text { Distance from acetabular axis to ante- } \\
\text { rior end of sacrum } \ldots \ldots \ldots \ldots \ldots\end{array}$ & 30 & 35 & & \\
\hline $\begin{array}{l}\text { Distance between ventral inner margins } \\
\text { of the acetabula } \ldots \ldots \ldots \ldots \ldots \ldots\end{array}$ & $14 \cdot 5$ & 15 & & \\
\hline
\end{tabular}

\section{Podicepes, sp. inc.}

The proof of the former existence of Grebes in the Mare aux Songes rests upon one single bone only, the right ulna; but the latter agrees in all the essential points with the corresponding bone of the genus Podicepes, notably the configuration of the proximal and the distal articulations, and the existence of a sharply marked groove at the upper outer distal condyle for the passage of the tendons of the extensor muscles, and differs in all these characters from the corresponding bones of any other birds which might otherwise possibly be taken into consideration, that doubts are excluded. The total length of this ulna is $82 \mathrm{~mm}$. It is consequently far too long and strong for P. pelzelni, P. minor, or P. philippensis. On the other hand, it is much too short for $P$. cristatus and by $10 \mathrm{~mm}$. shorter than that of $P$. ruficollis. It is, however, slightly longer than the ulna of either $P$. cornutus or $P$. auritus, so that it probably belonged to an insular form of one of these last-named species.

\section{Butorides mauritianus, sp. nov. (Plate XXXIV. figs. 6-8.)}

It is surprising that of all the Ardeine bones, referable to at least twelve individuals of five different species, none belong to Ardea (Butorides) nigricollis, the only species of Heron at present existing in Mauritius, while a pair of ulnæ, one radius, four metatarsi, and one coracoid must be considered as belonging to a species of shortfooted Heron hitherto unknown. The bones in question are all considerably shorter than the corresponding bones of $A$. (Nycticorax) megacephala. The metatarsi agree otherwise in every detail with those of the latter species; this relative stoutness indicates that they belonged to a Night-Heron or Bittern like A. megacephala. The two ulnæ cannot, unfortunately, be compared with those of $A$. megacephala; their length, $110 \mathrm{~mm}$., compared with the length of the humerus of A. megacephala, $119 \mathrm{~mm}$., shows, however, likewise that they were those of a considerably smaller bird.

vol. XIII.-PART viI. No. 2.-August, 1893. 
The single left coracoid agrees in all the features of its dorsal or scapular half with A. megacephala, but its ventral or sternal half differs considerably, first by the much more strongly marked ridge of the linea intermuscularis on its ventral surface, secondly by the almost straight instead of inwardly curved margin between the processus lateralis and the lateral distal corner of the sternal articulation, thirdly by a very low but very distinct and sharp ridge which arises from the median margin of the coracoid a little above its median articulating corner. This roughness or prominent ridge is entirely absent in $A$. megacephala and in all other Herons which we have been able to examine, but at least a slight indication of it occurs in an individually varying degree in Nycticorax and in Botaurus. That this coracoid bone belonged, however, to an Ardeine bird is clearly indicated by its whole configuration, notably by the shape and position of the precoracoid process, the various articulating facets at the dorsal end, and the prominent lip on the visceral or internal surface of the median portion of the sternal articulating facet.

$\begin{array}{lcc} & \begin{array}{c}\text { Butorides mauritianus. } \\ \mathrm{mm} .\end{array} & \begin{array}{c}\text { Nycticorax megacephala. } \\ \mathrm{mm} .\end{array} \\ \text { Length of ulna } \ldots \ldots \ldots \ldots & 111-112 & \ldots \\ \text { Length of metatarsus ...... } & 81-87 & 96 \\ \text { Length of coracoid ....... } & 48 & 55\end{array}$

7. Sarcidionnis madritianus, sp. nov. (Plate XXXIV. figs. 9, 10.)

The most tangible proof of the former existence of this form in the island of Mauritius rests at present upon one specimen of left metacarpal bones. However, this solitary specimen is sufficiently well preserved to show its affinities by various well-marked characters. It agrees in size with the corresponding combination of bones of Bernicla brenta, while it is considerably smaller than those of the common domesticated Anser cinereus, and too large for the Madagascar and East-African Sarcidiornis africanus and the Indian $S$. melanonotus.

The generically diagnostic feature of the bones of the middle hand of Sarcidiornis is the very prominent process which arises from the side of the first metacarpal, proximally from the articulating facet of the pollex. The apex of this process is covered in Sarcidiornis by a skin, which, although thickened and bare of feathers, is not transformed into a horny callosity or spur. The same peculiar feature exists in the bone before us; the apex is rough and irregularly shaped, and since this part of the process never serves for the origin or insertion of muscles or tendons, its roughness plainly indicates the same purpose as that of the Madagascar species of Sarcidiornis, namely its use as a fighting knuckle, although in an either arrested or incipient state. Such a weapon, furnished with a sharp and long horny spur with bony core, carried by the first metacarpal bone, is fully developed in Chauna. This American genus 
can of course not be compared with the bird from Mauritius except by analogy. The only truly "spurred Goose" of the Ethiopian region is Plectropterus; but the spur is carried by the radial carpal bone and therefore is at once removed from comparison with our specimen, which belonged to a rather large-sized species of Sarcidiornis, and, having probably been restricted to the island of Mauritius, may be distinguished as S. mauritianus.

Another part of this bird consists of the somewhat incomplete left half of the pelvis; it agrees in size with that of Bernicla brenta, consequently by inference with Sarcidiornis, measuring $70 \mathrm{~mm}$. from the anterior brim of the acetabulum to the posterior end of the os ischii. The few characters which are preserved in this portion of a pelvis agree with those of Anas and Anser and other Lamellirostres.

\section{Anas theodori, sp. nov. (Plate XXXIV. figs. 11-17.)}

The fragment of a sternum, a pair of coracoids, eight humeri, and a pair of metatarsi are referable to a Duck which was considerably larger than Nettapus auritus, Anas bernieri, and Dendrocygna, but smaller than Anas melleri, of which we have a skin and breast-bone with shoulder-girdle for comparison.

Of the sternum only the anterior portion is preserved, which is, however, sufficient to show its affinities. Its width between the two lateral muscular ridges of the sternum is $28 \mathrm{~mm}$, i.e. slightly less than in Anas melleri and agreeing with Dendrocygna arcuata; the sternum differs, however, from that of Dendrocygna by its welldeveloped, although broken-off spina externa, by its lower keel, and lastly by the much smaller and shallower entrance to the pneumatic foramen; it differs also from that of $A$. melleri by the lesser height of the keel, moreover by the shape and direction of the anterior margin of the latter.

The single left coracoid is in a perfect state of preservation and fits well into the sternal fragment, so that it might belong to the same species, although certainly not to the same individual. This coracoid differs from that of Dendrocygna by its greater length, by the shape of its sternal end, and by its very smooth, almost plain ventral surface. Nettapus and Anas bernieri are to be excluded on account of their much smaller and shorter coracoids. The coracoid in question is much shorter than that of A. melleri, but it agrees closely with the latter by its shape, and especially by the almost plain ridgeless ventral surface of the shaft.

The seven humeri are much like each other, but vary from 70 to $78 \mathrm{~mm}$. in their greatest length; they are exactly of the same shape and size as those of different specimens of Anas punctata, i. e. of a much smaller Duck than A. melleri.

The two metatarsi are in a bad condition; the right one measures $42 \mathrm{~mm}$. in length, indicating a bird much more short-footed than A. melleri. 


\begin{tabular}{|c|c|c|}
\hline & $\begin{array}{c}\text { A. theodori. } \\
\text { mm. }\end{array}$ & $\begin{array}{c}\text { A. melleri. } \\
\text { mm. }\end{array}$ \\
\hline Width between pectoral ridges..$\ldots \ldots \ldots$ & 28 & 30 \\
\hline Distance from spina interna to top of crest .. & 20 & 25 \\
\hline Length of coracoid..... & 42 & 52 \\
\hline Length of humerus $\ldots .$. & $70-78$ & 89 \\
\hline Length of metatarsus $\quad \ldots \ldots \ldots$ & 42 & 41 \\
\hline
\end{tabular}

The result of our investigations is that the bones figured (Plate XXXIV. figs. 11-17) belong to a Duck which differs from any of those found in Madagascar, while it agrees more closely with $A$. melleri but for its dimensions, which are so much smaller that they cannot well be accounted for by individual variation. It is moreover the only Duck of which remains have hitherto been found in Mauritius; we distinguish it therefore as Anas theodori, in honour of Mr. Théodore Sauzier.

9. Fulica newtoni. (Plate XXXV. figs. 1-11.)

The remains of this large Coot are numerous. The femur, sternum, humerus, and four cervical vertebræ are new and hitherto not described, while the whole pelvis and sacrum, the tibia, and the metatarsus have been described by M. Milne-Edwards. The bones belonged to at least 24 different individuals, and show accordingly a considerable amount of variation in their dimensions.

The smallest thigh-bone is 76 , the longest $90 \mathrm{~mm}$. long. The latter is larger in all its dimensions, otherwise alike the others. The outer or superior trochanteric crest is high and curved inwards; the two principal arms of the tendinous loop for the $\mathrm{m}$. biceps cruris have left two very distinct impressions on the lateral surface of the distal end of the shaft and near the popliteal region. The external condyle has a deep and smooth notch for the reception of the head of the fibula.

The pelvis agrees with that of Fulica proper and with that of Tribonyx because of the peculiar dip of the dorsal margin of the pre-acetabular ilium, which does not reach up to the level of the dorsal spinous processes, leaving a long groove through which passed the tendons of the usually obliterated dorsal spinal muscles. In the possession of this groove and in its elongated and laterally contracted shape this pelvis agrees with that of a typical Fulica, and it differs much from that of Aphanapteryx and Ocydromus, while the pelvis of Porphyrio melanonotus and that of Tribonyx are less contracted than in Fulica and Gallinula.

The sternum of F. newtoni resembles in several points that of Aphanapteryx, Erythromachus, and Ocydromus, and differs from Tribonyx, Fulica proper, and Porphyrio, first in the configuration of the whole anterior margin of the sternum, especially in the double or basally divided spina externa, which is moreover broad and flat, while in the other genera this spine is single and furnished with a ventral longitudinal sharp ridge; secondly, by the receding and broad anterior margin of the keel, which, however, is well developed, although less than in Tribonyx and Fulica atra, but the tendency towards a reduction of the keel is apparent. 
The shortest humerus is 8.5 , the longest $92 \mathrm{~mm}$. in length. They all differ from that of Aphanapteryx by being far less curved, stronger throughout, and furnished with a large pneumatic foramen; the sulcus transversus upon the head of the humerus is deeper, but the tuberculum medium is lower.

The cervical vertebræ of the Rallidæ can be easily recognized by their shape and by the numerous articulating facets, processes, and median crests. On the whole, these vertebræ of $F$. newtoni resemble more closely those of Porphyrio and Ocydromus than those of Fulica proper. Dorsal spinous processes are absent in the 9th and 10th vertebræ, they are rather low in the 6 th and 5th, sharp and high in the 4th. Ventral median processes are absent in the 10 th to 5 th, high in the 4 th and 3rd. The latter two vertebræ are marked by a deep round notch on each side, this notch being often turned into a complete foramen. Most of the lower and middle vertebræ of the neck are very broad in comparison with their length.

In conclusion, we feel inclined to think that the Fulica newtoni combines important characters of the true genus Fulica with those of Porphyrio, Tribonyx, and Ocydromus, and that on the whole it more resembles these last three than the true Waterhens.

\section{Aphanapteryx broecki. (Plate XXXV. figs. 12-20.)}

Only the tibia, tarso-metatarsus, and underjaw were hitherto known, described and figured by M. Milne-Edwards. Besides the tibiæ and tarso-metatarsi of many individuals, we have now before us the pelvis with sacrum, femora, and humeri; one sternum, one third cervical vertebra, and one nearly complete premaxilla, together with fragments of the upper and lower jaws. It has been comparatively easy to determine most of these new bones because of their close resemblance to the corresponding parts of Erythromachus.

The pelvis, with the sacrum, of one specimen is extremely well preserved. It is much more compact, stouter, shorter, and broader than that of Fulica newtoni; the dorsal margin of the pre-acetabular part of the ilium reaches up to the dorsal spinous crest of the anchylosed presacral vertebræ, as is also the case in Ocydromus and Porphyrio. In their general configuration the pelvis and sacrum of Aphanapteryx agree with Erythromachus.

The femur, essentially similar to that of Fulica, Porphyrio, and other allied Rails, can be distinguished from that of Fulica newtoni by its smaller dimensions.

The tibia and metatarsus, having been described and figured previously, need not be commented upon, beyond stating that they, especially the metatarsus, are relatively stouter than those of Fulica.

The sternum and humerus are of particular interest, because of their small size, and because of the absence of any large pneumatic foramina, indicating that this bird was devoid of the power of flight. The sternum is not complete, its posterior portion being absent. Its width across the level of the first rib behind the anterior lateral process is only $25 \mathrm{~mm}$.; the keel is very much suppressed, with its anterior margin broadened 
out and deeply grooved, as in Erythromachus. There is no trace of a spina interna; the feet of the coracoids, as indicated by their facets, were separated from each other by a smooth groove of $9 \mathrm{~mm}$. in length. The spina externa is represented by two projections from the ventral lips of the median corner of the coracoid articulation. In this respect Aphanapteryx agrees with Erythromachus, and also with Fulica newtoni.

The humerus is very short and slender for so large a bird; its typically Ralline characters are, however, obvious enough to recognize it as belonging to Aphanapteryx, while it differs by its far greater length and strength from the humerus of Gallinula, and by its much smaller dimensions from that of Fulica. A very interesting feature is the absence of the usually wide and deep pneumatic foramen, which is indicated only by a shallow depression which is smaller than even in Gallinula chloropus.

The third cervical vertebra could easily be recognized as such by its numerous Ralline characters, which in these birds are strongly pronounced; its dimensions remove it from either Fulica or Gallinula, $i$. e. from the only other Ralline birds hitherto known to have occurred in Mauritius.

The premaxilla fits well upon the several fragments of underjaws, and still better upon the underjaw figured by M. Milne-Edwards. The great length and the shape of these bones closely resemble those of Erythromachus (Phil. Trans. vol. 168, pl. xliii. fig. A). The Mauritian bird is, in fact, nothing but a larger species of the same genus.

A number of measurements are given in the subjoined Table in order to aid the comparison of the Mauritian Ralline birds with each other and with some of their allies.

\begin{tabular}{|c|c|c|c|c|}
\hline & Fulica newtoni. & $\begin{array}{c}\text { Aphanapteryx } \\
\text { broecki. }\end{array}$ & $\begin{array}{c}\text { Porphyrio } \\
\text { melanonotus. }\end{array}$ & $\begin{array}{l}\text { Ocydromus } \\
\text { australis. }\end{array}$ \\
\hline 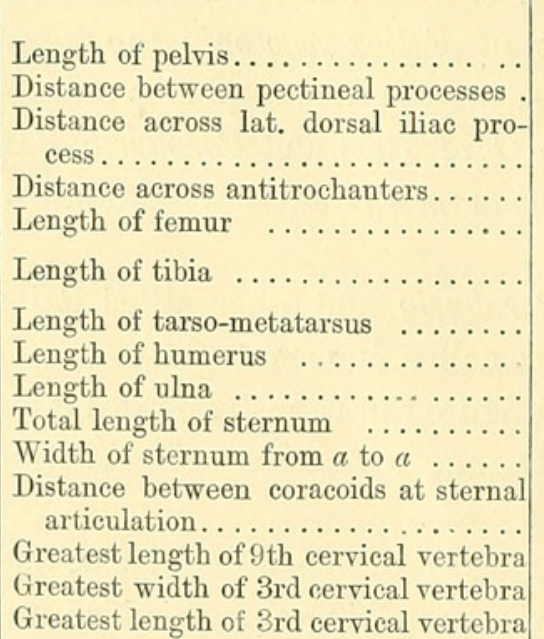 & $\begin{array}{c}\mathrm{mm} . \\
80 \\
23 \cdot 0 \\
28 \\
32 \\
76,78,81,90 \\
120,127 \\
130,133 \\
82-84 \\
85,88,90,92 \\
74 \\
70 \\
29 \cdot 5-30 \\
5 \\
17-21 \\
15 \\
16\end{array}$ & 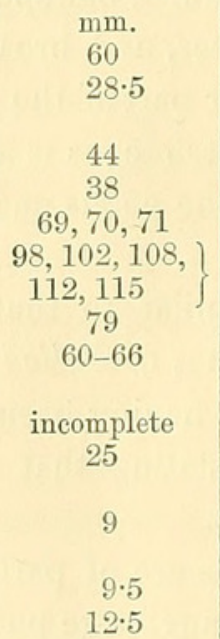 & $\begin{array}{r}83 \\
140 \\
98 \\
88 \\
\\
68 \\
22 \\
\\
2.5\end{array}$ & $\begin{array}{r}82 \\
111 \\
62 \\
57 \\
\\
55 \\
20\end{array}$ \\
\hline
\end{tabular}




\section{TROCAZA MEYERI.}

Five fractured breastbones can easily be recognized as Columbine by the combination of the following characters :-The very high and at the same time slender or thin crista ; the presence of a well-developed spina interna, which is broad at its base, ending anteriorly obtuse and slightly bifurcated, while the spina externa is by far less developed; lastly, the deep and regular grooves for the articulation with the coracoids, which do not meet each other, but are separated by a smooth, scarcely prominent, median ridge.

In order to determine the species we have compared the bones with those of Turtur picturatus, Vinago australis, Funingus madagascariensis, and Trocaza meyeri. The bones of the first three are figured by M. Milne-Edwards, of the last two the Cambridge Museum possesses skeletons. The result of this comparison showed that four breastbones belong to Trocaza meyeri.

In this species there exists a small but distinctly prominent tubercle on the labium internum of the anterior margin of the sternum, midway between the anterior end of the spina interna and the base of the lateral anterior process of the sternum; it serves for the attachment of the inner accessory sterno-coracoidal ligament. This tubercle is well developed in the four breastbones, as in Trocaza, very small in Funingus, and absent in Turtur and Vinago.

A second specific character is afforded by the spina externa of the sternum, which is well developed in Trocaza and Vinago, small in Turtur, absent in Funingus.

The measurements on the following page show, moreover, additional characters, which led to the determination of the species to which the breastbones belong.

Three tarso-metatarsal bones likewise are referable to Trocaza meyeri, because of their length and the configuration of the bony ridges and furrows on the posterior side of the proximal end of the tarso-metatarsus, serving for the passage of the various long flexor muscles of the toes. In this respect Trocaza agrees, but for the length of the bones, with Turtur, and differs considerably from Funingus.

\section{Funingus, sp. inc.}

One sternum, unfortunately very incomplete, consisting only of the anterior end, with the anterior margin of the sternum and the anterior margin of the keel, may possibly belong to Funingus, chiefly on account of the absence of the lateral tubercles of the spina interna, and because of several of its dimensions as given in the following Table, in which this specimen is marked M.S.= Mare aux Songes, while E.N. indicates obtained in the flesh by Sir Edward Newton, and M.E. that the specimen has been figured by M. Milne-Edwards. 


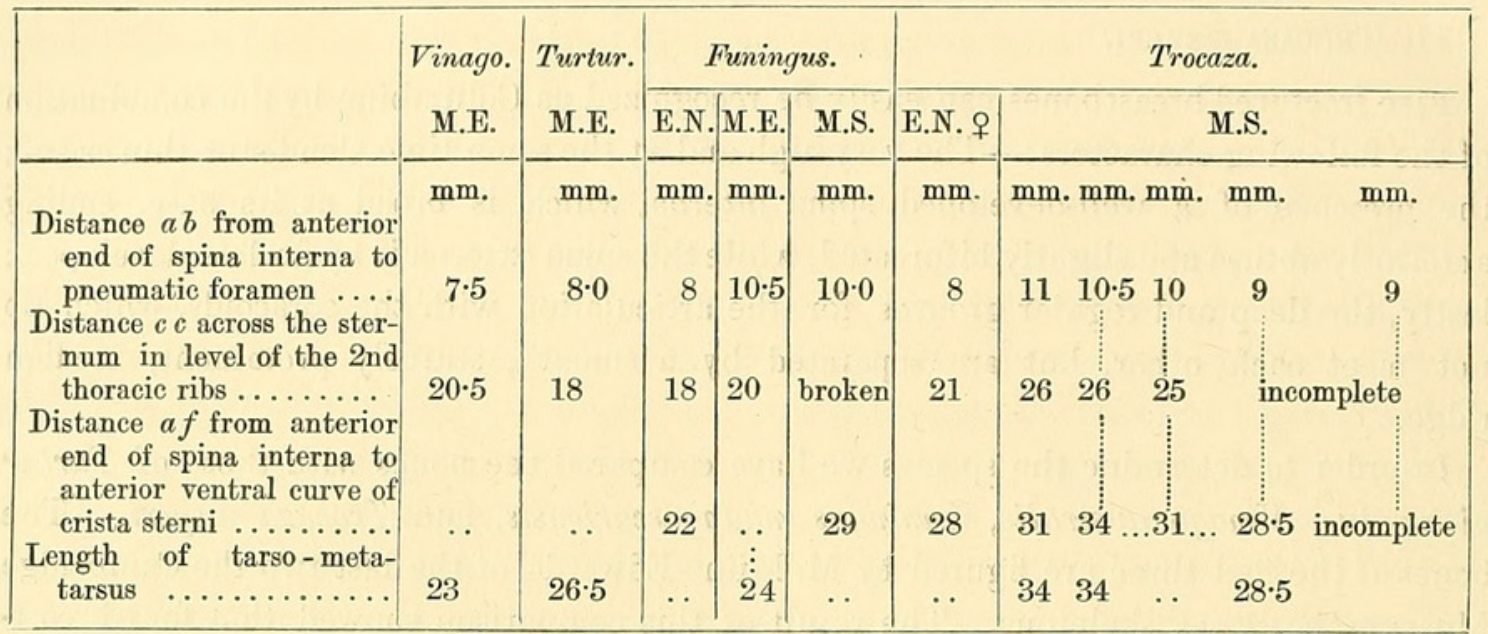

There are also five ulnæ of a Pigeon, which could not, however, be further determined except that they belong to either Trocaza or Funingus.

\section{Didus ineptus. (Plates XXXVI., XXXVII.)}

The new material of bones of the Dodo has enabled us to add to the restoration of the skeleton the following parts which have hitherto not been known :-

1. The median distal portion of the furcula appears to be devoid of an "apophyse médiane" or hypocleidium, this region being rounded off. This may, however, be a case of individual variation, considering that in the male specimen of the Cambridge Pezophaps there is likewise no apophysis, while there is one, although small, in the female specimen. Hence, Professor Owen's restored drawing of this part in the British Museum specimen of Didus cannot be pronounced to be incorrect.

2. Metacarpal bones of the right and left side, and the first phalanx of the second finger. These bones present no remarkable features, and agree in their small size with the much reduced state of the other bones of the wings. There is, moreover, no evidence of the existence of those peculiar exostoses on the distal end of the radius and on the first metacarpal that are so characteristic of the male Solitaire, which probably used them as fighting-knuckles.

3. The distal third of the pubic bones.

4. Phalanges of the toes (hitherto known from the Oxford specimen only).

5. The atlas or first cervical vertebra.

The most interesting result of the examination of the bones entrusted to us by $\mathrm{Mr}$. Sauzier is the determination of the number of vertebræ and ribs which belong to the various regions of the skeletal axis.

Hitherto our knowledge of these parts has rested upon the mounted specimen in the 
British Museum (and the restored drawings by Professor Owen in the Trans. Zool. Soc. vi. and vii.), which is faulty, and upon the Cambridge skeleton, which was incomplete. Hence all the references to the number of vertebræ and ribs are also at fault $(c f$. Fuerbringer's ' Untersuchungen für Morphologie und Systematik der Vögel,' tabb. xxi. \& xxii. pp. 778-781; and Bronn's 'Thier-Reich, Vögel,' p. 950).

The vertebræ examined by us belong to an unknown number of individuals. Moreover, it is not possible to pick out a complete series from the atlas to the pelvis, which without doubt belonged to one and the same individual. Lastly, it is a curious mishap that only a single specimen has been found of that vertebra which fits into the gap between the last of the three anchylosed thoracic vertebræ and the first vertebra which is overlapped by and fused with the pelvis.

The determination of the number of vertebræ composing the various regions of the vertebral column has consequently to rest upon circumstantial evidence. An unbiased collection of facts from other Pigeons reveals certain correlations of number and shape of vertebræ and ribs, and the results thus gained can be applied to the restoration of the Dodo's skeleton with a considerable amount of probability.

It seems to be the rule in normal (not domesticated) Pigeons that :-

1. The 15 th, 16 th, and 17 th vertebræ are anchylosed together.

2. The 18th vertebra is free, articulating in front with the $17 \mathrm{th}$, and behind with the 19th vertebra, which latter in all cases is overlapped by, and partly fused with, the pelvis. For the sake of convenience the 18 th may be called the intermediate vertebra.

3. The 14th and 13th vertebræ each possess a spinous process which is hookshaped.

4. Complete ribs, $i . e$. such as articulate with the sternum, vary from 3 to 4 in number, and are restricted to the 15 th to 19 th vertebræ, while the 16 th to 18 th always carry complete sternal ribs.

5. Cervico-dorsal vertebræ are those which carry movable short ribs; the dorsal portion of such a rib articulates by a typical capitulum and tuberculum with one vertebra, while the ventral or distal half of the rib is lost. As a rule, at least, the last of these short ribs carries an uncinate process. The number of cervico-dorsal vertebræ is two, rarely three.

6. The other neck-vertebræ are true cervical vertebræ; with the exception of the atlas and the epistropheus, they all possess a transverse foramen and immovable ribrudiments.

7. In recent Pigeons the last or hindmost pair of complete sternal ribs is frequently followed by one pair of ribs which, attached to the 19th, or 1st pelvic, vertebra, almost reaches the sternum: in rare cases there is present even a second, although much shorter pair, which then belongs to the 2nd pelvic or 20 th vertebra.

The following Table will show these modifications :voL. XIII.-PART VII. No. 3.-August, 1893. 
C indicates the last true cervical vertebra.
$h \quad$ st indicates a sternal rib.
$r \quad$ a hooked spinous process.

\begin{tabular}{|c|c|c|c|c|c|c|c|c|c|}
\hline Serial number of vertebræ .......... & 12 & 13 & 14 & \multicolumn{3}{|c|}{ anchylosed } & $\begin{array}{c}18 \\
\text { inter- } \\
\text { mediate. }\end{array}$ & $\begin{array}{c}19 \\
1 \text { st } \\
\text { pelvic. }\end{array}$ & $\begin{array}{c}20 \\
\text { 2nd } \\
\text { pelvic. }\end{array}$ \\
\hline Columba livia... & $\mathrm{C}, h$ & $h, r$ & $r, u$ & $s t$ & $s t$ & st & st & $\begin{array}{l}\text { almost } \\
\text { sternal }\end{array}$ & no rib \\
\hline Phaps chalcoptera .... & C & $h, r$ & $h, r, u$ & st & st & $s t$ & $s t$ & ” & long rib \\
\hline Didunculus strigirostris . & C & $h, r$ & $h, r$ & st & $s t$ & st & st & " & no rib \\
\hline Treron olax $\ldots \ldots \ldots$ & . & $\mathrm{C}, h$ & $h, r$ & $r, u$ & st & st & st & $"$ & \\
\hline Carpophaga pacifica . . & . & $\mathrm{C}, h$ & $h, r$ & $r, u$ & $s t$ & st & st & " & no rib \\
\hline Goura coronata ........ & . & $\mathrm{C}, h$ & $h, r$ & $r, u$ & st & st & st & ” & \\
\hline Pezophaps solitaria, o & . & $\mathrm{C}, h$ & $h, r, u$ & $r, u$ & st & st & st & st & $\begin{array}{l}\text { short } \\
\text { rib }\end{array}$ \\
\hline$-\longrightarrow$, & . & $\mathrm{C}, h$ & $h, r$ & $r, u$ & $s t$ & $s t$ & $s t$ & st & " \\
\hline $\begin{array}{l}\text { Didus ineptus, properly restored, Cam- } \\
\text { bridge and Mauritius Museums.... }\end{array}$ & . & C, $h$ & $h, r$ & $r, u ?$ & st & $s t$ & st & $s t$ & no rib \\
\hline 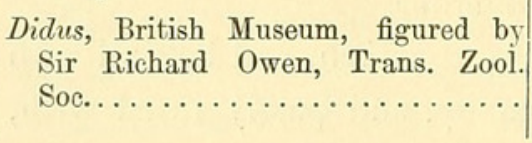 & C & $r$ & $r, u$ & st & st & st & st & st & $\begin{array}{l}\text { almost } \\
\text { sternal }\end{array}$ \\
\hline
\end{tabular}

Didus agrees with Pezophaps in possessing 13 cervical vertebræ, 2 short ribs, 4 sternal ribs, the last being carried by the first pelvic vertebra.

Treron, Carpophaga, and Goura agree with each other in having 13 true cervical vertebræ, 2 short, 2 sternal, and 1 almost sternal pairs of ribs. They differ from Didus and Pezophaps in the latter pair of ribs being withdrawn from the articulation with the sternum.

Columba, Phaps, and Didunculus differ from the others in having only 12 true cervical vertebræ, 2 short, 4 sternal, and 1 almost sternal pair of ribs, because their 15 th or first anchylosed vertebra (instead of the 16th or 2 nd anchylosed vertebra) carries the first pair of sternal ribs.

The restoration in the Trans. Zool. Soc. vi. pl. 15 contains one pair of sternal ribs and one vertebra (the 15 th in the figure) too many.

In conclusion we wish to say that, beside the Birds' bones here described, the explorations of Mr. Sauzier have produced very many bones of Reptiles, which will be treated of by one of us in a subsequent paper, together with a considerable number of shells of Mollusks, portions of Crustacean integument, and a few pieces of Coral. The presence of these marine forms in the soil of the Mare aux Songes may be, it is believed, attributed to the action of Land-Crabs, for there is no reason to think that 
the sea has ever had access to the lake, from which it is separated by a ridge of some height, while it is known to be the habit of those creatures to convey animal remains a long distance inland from the shore. Nevertheless it may be as well to name the shells as determined by Mr. A. H. Cooke, Honorary Curator of Conchology in the Cambridge Museum. They are as follows:-Land Mollusca, Gibbulina sulcata, Lam., Pachystyla inversicolor, Fér., Cyclostoma carinatum, Lam.: Marine Mollusca, Cyproea caput-serpentis, L., Nerita polita, L., Turbo sp. incert. (fragment). In addition to the foregoing the seeds of several plants have also been found, but these appear not to need enumeration; nor do the specimens of the soil collected by Mr. Sauzier (though all are carefully preserved in the Museum) seem to call for any particular remark on the present occasion.

\section{EXPLANATION OF THE PLATES.}

\section{PLATE XXXIII.}

Figs. 1-8. Lophopsittacus mauritianus (p. 283).

Fig. 1. Left tibia, front view. $l$, attachments of the transverse ligament across the long extensor tendons.

Fig. 2. Right femur, posterior view.

Fig. 3. Left metatarsus, plantar surface.

Fig. 4. Left metatarsus, dorsal surface. $g$, groove for the tendon of the musc. extensor digitorum ; $i$, insertion of the tendon of the $\mathrm{m}$. tibialis anticus.

Fig. 5. Dorsal view of the underjaw. $p$, posterior angle; $f$, facet for the quadrate; $f i$, additional facet for the jugal process of the quadrate.

Fig. 6. Lateral view of the right jaw.

Fig. 7. Ventral view of sternum. Sp.e., spina externa sterni; p.l.a., anterior lateral process ; $S$, lateral line of $\mathrm{m}$. subclavius.

Fig. 8. Right lateral view of sternum. Sp.i., spina externa sterni; $S$, median line of m. subclavius.

Figs. 9 and 10. Astur alphonsi (p. 285).

Fig. 9. Left tibia, front view. $f$, rest of fibula; $b$, bony bridge over the tendon of the m. extensor digitorum; $p$, peroneal crest.

Fig. 10. Left metacarpals, lateral view. $p$, articular facet of the pollex; $m_{3}$, metacarpale III.

Figs. 11-18. Strix sauzieri (p. 286).

Figs. 11, 12. Inner and outer views of humerus. $f$, pneumatic foramen.

Fig. 13. Left tibia, front view. $p$, peroneal crest; $f$, distal portion of fibula ; $l$, attachment of transverse ligament. 
Figs. 14, 15. Posterior and anterior views of right tarso-metatarsus. $b$, bony bridge across the tendon of the $\mathrm{m}$. tibialis anticus; $h$, facet for the hallux's metatarsal; $i$, insertion of the m. tibialis anticus.

Fig. 16. Proximal end of the tarsus.

Figs. 17, 18. Posterior and anterior views of the small pair of tarso-metatarsals.

\section{PLATE XXXIV.}

Figs. 1-5. Plotus nanus (p. 288).

Figs. 1, 2. Dorsal and ventral views of pelvis. $I$, first vertebra fused with sacrum; T.I, primary sacral vertebra; $p b$, os pubis ; at, antitrochanter.

Fig. 3. Inner or median view of left humerus.

Fig. 4. Outer or lateral view of left humerus. C.s, crista superior; S.t, sulcus for the humero-coracoid ligament; T.s, tuberculum superius s. externum; s.a.l, sulcus anconæi lateralis; s.a.m, sulcus anconæi medialis; $b . i$, origin of the m. brachialis inferior.

Fig. 5. Anterior view of left tibia. $p$, peroneal crest; l.c, lateral cnemial crest.

Figs. 6-8. Butorides mauritianus (p. 289).

Figs. 6, 7. Dorsal and ventral views of left coracoid. $l . i$, linea intermuscularis ; p.l, prominent lip; $p r$, precoracoid process; $r$, rough ridge.

Fig. 8. Posterior plaṇtar view of right tarso-metatarsus. $h$, attachment of metatarsale I.

Figs. 9 and 10. Sarcidiornis mauritianus (p. 290).

Fig. 9. Lateral view of metacarpals of left wing.

Fig. 10. Median or ventral view. M.I, rough knob of first metacarpal ; $P$, articulation of pollex ; $f$, facet for the os carpale ulnare.

Figs. 11-17. Anas theodori (p. 291).

Fig. 11. Left lateral view of sternum. Sp.e, spina externa; $l$, lateral line of $\mathrm{m}$. subclavius.

Fig. 12. Anterior margin of sternum. $K$, keel.

Fig. 13. Ventral view of left coracoid.

Figs. 14, 15. Right humerus. $s$, sulcus for ligament. humero-scapulare ; C.s, crista superior ; $b . i$, origin of $\mathrm{m}$. brachialis inferior.

Fig. 16. Posterior or plantar view of right tarso-metatarsus.

Fig. 17. Proximal end of the same. 


\section{PLATE XXXV.}

Figs. 1-11. Fulica newtoni (p. 292).

Fig. 1. Dorsal view of premaxilla.

Fig. 2. Dorsal view of third cervical vertebra.

Fig. 3. Dorsal view of either ninth or tenth cervical vertebra.

Fig. 4. Ventral view of either ninth or tenth cervical vertebra.

Fig. 5. Sternum from the right side. p.l.a, anterior lateral process; Sp.e, spina externa; $s$, ridge of $\mathrm{m}$. subclavius.

Fig. 6. Sternum from the ventral side. $a$, distance of $30 \mathrm{~mm}$.

Fig. 7. Sternum from the dorsal side. C.s, attachment of ligament between sternum and coracoid.

Fig. 8. Lateral view of left humerus. S.t, sulcus transversus.

Fig. 9. Median view of left humerus. C.s, crista superior ; t.m, tuberculum medium.

Figs. 10, 11. Anterior and posterior views of left femur. $B$, attachment of sling of biceps muscle; $F$, facet for the fibula.

Figs. 12-20. Aphanapteryx broecki (p. 293).

Fig. 12. Premaxilla and mandible; lateral view.

Fig. 13. Dorsal and ventral views of third cervical vertebra. p.t, posterior zygapophysis.

Figs. 14, 15, 16. Ventral, dorsal, and lateral views of sternum. $T$, tubercle for attachment of sterno-coracoid ligament; $K$, anterior end of keel.

Fig. 17. Lateral view of left humerus. t.m, tuberculum medium, much higher than in Fulica.

Fig. 18. Median view of left humerus.

Fig. 19. Ventral view of pelvis and sacrum. $p \cdot p$, pectineal process; $S_{\boldsymbol{I}}$, primary sacral vertebra.

Fig. 20. Right lateral view of pelvis. $A$, antitrochanter ; $p . i$, posterior lateral dorsal process of ilium ; $P$, os pubis.

\section{PLATE XXXVI.}

Didus ineptus (p. 296).

Fig. 1. The first correctly restored and properly mounted skeleton of the Dodo. The specimen belongs to the Government Museum of Mauritius. The left wing and ribs have not been drawn, in order to keep the drawing clearer. The 18th vertebra has been cross-shaded, because it was still unknown when the skeleton was restored. 
Figs. 2, 3, 4. Anterior, posterior, and lateral views of the atlas. Nat. size.

Fig. 5. Dorsal and ventral views of the metacarpals and of the first phalanx of the index.

\section{PLATE XXXVII.}

Didus ineptus (p. 296).

Figs. 1 A, B. Dorsal and lateral views of the posterior portion of the pelvis. Nat. size. Figs. 2 A, B, C. Lateral, anterior, and posterior views of the 18 th vertebra. Nat. size. Only one single specimen of this 18th vertebra was found amongst the hundreds of other vertebræ of the Dodo which have passed through our hands. This specimen is unique. The corresponding vertebra of the mounted skeleton in the British Museum is a cleverly executed artificial substitute. 

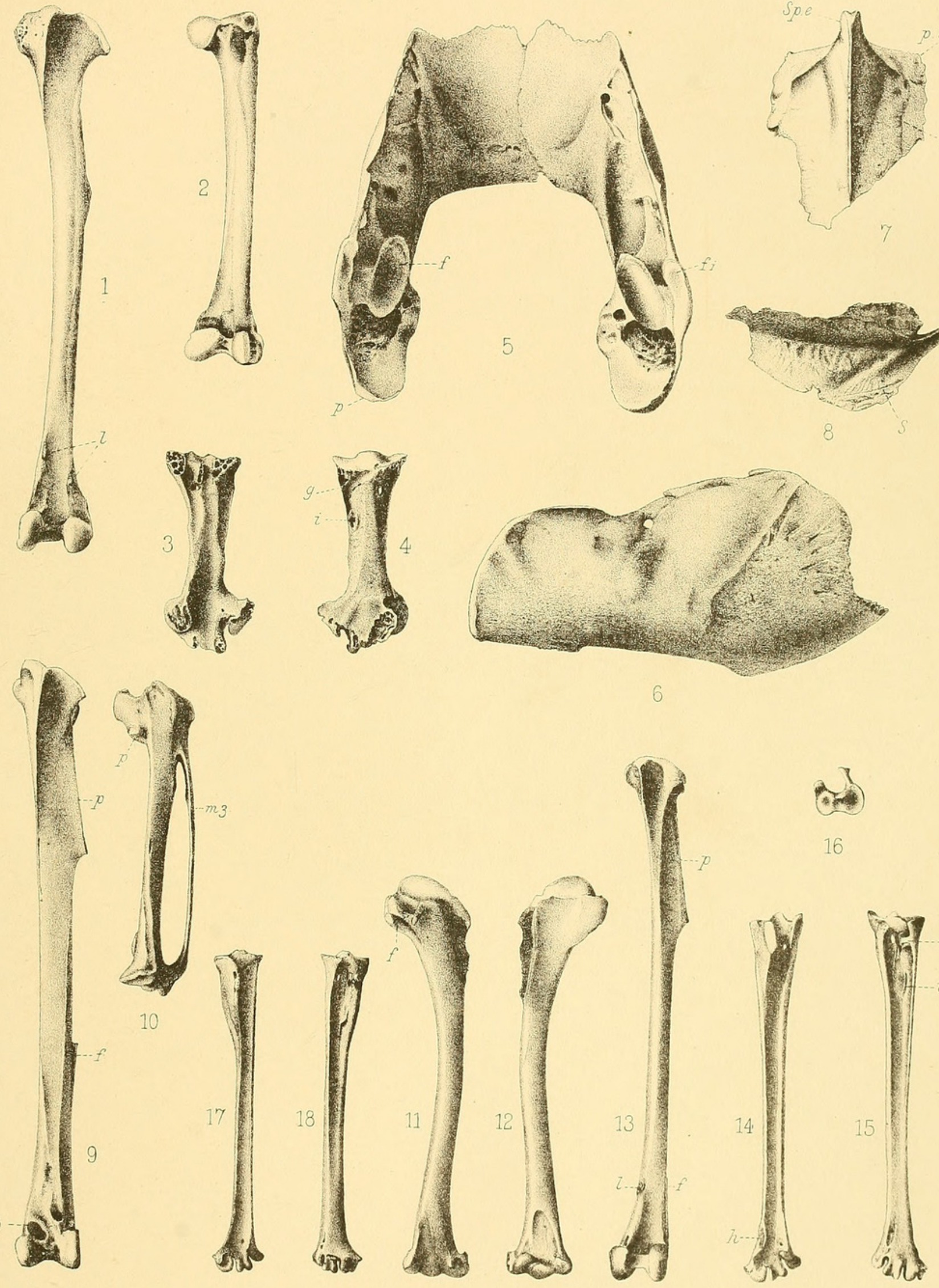

FIG.1-8 LOPHOPSITTACUS MAURITIANUS. FIG. 9-10 ASTUR ALPHONSI. 

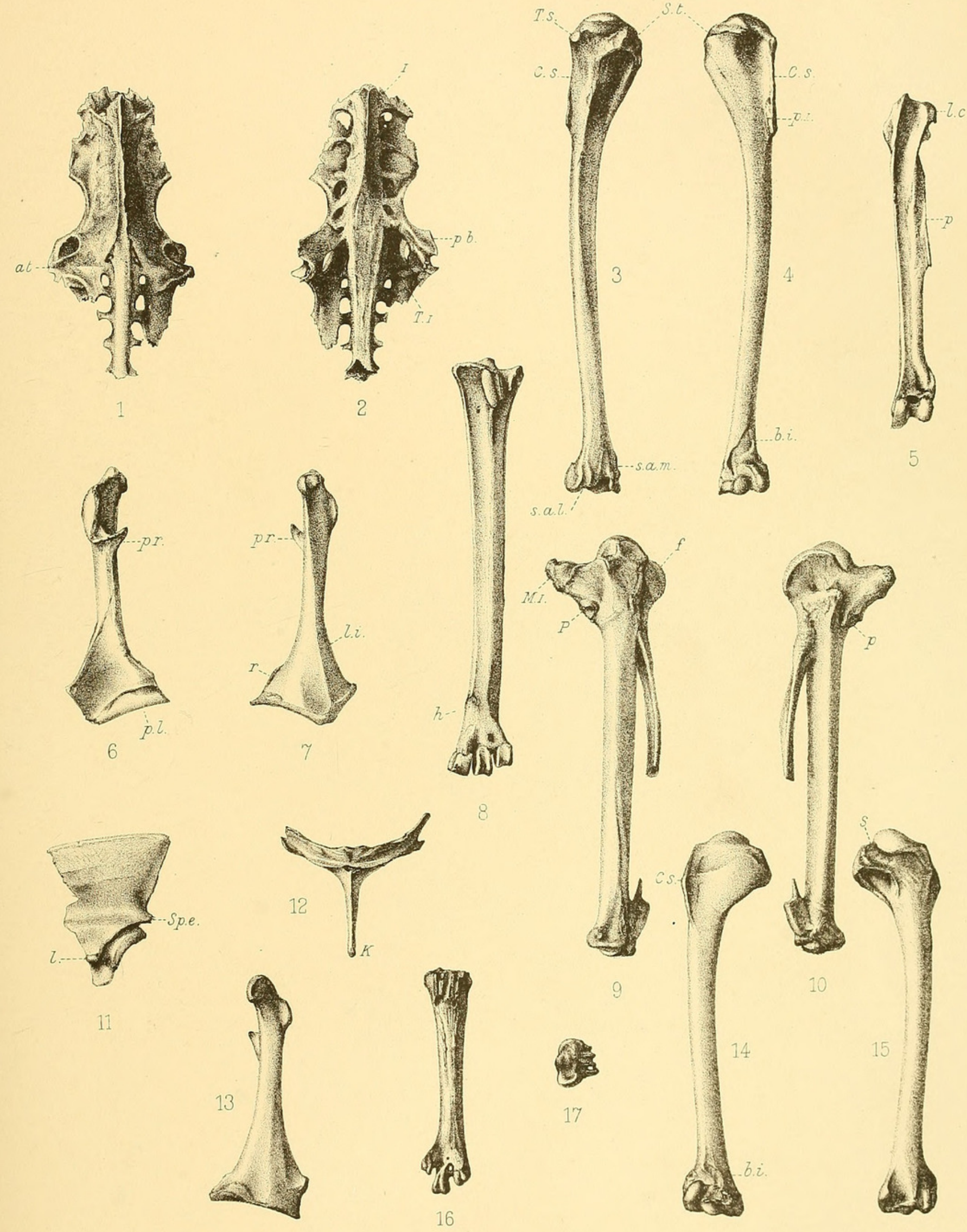

FIG 1-5 PLOTUS NANUS. FIG 6-8 BUTORIDES MAURITIANUS. FIG 9-10 SARCIDIORNiS MAURITIANA. 

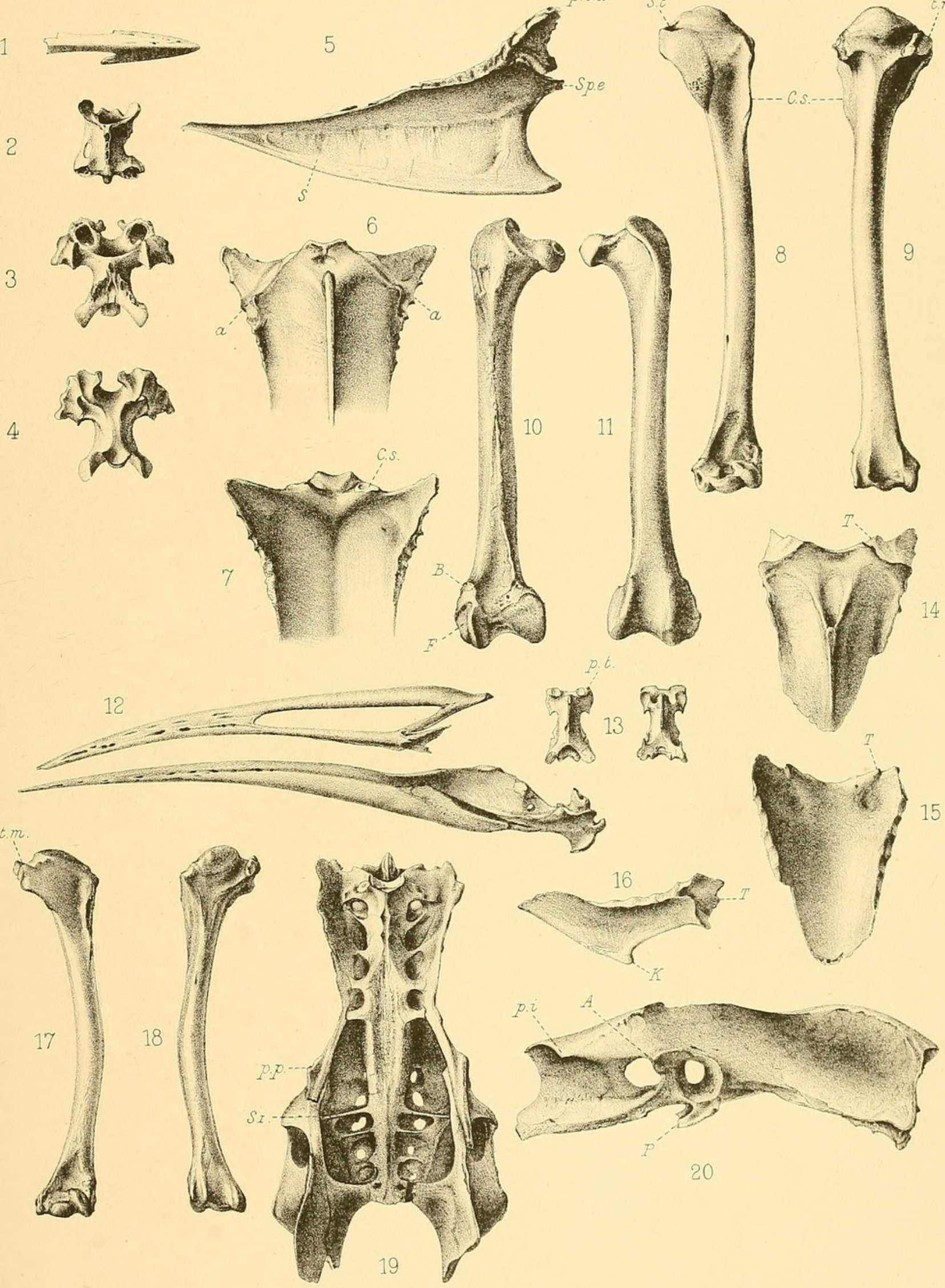


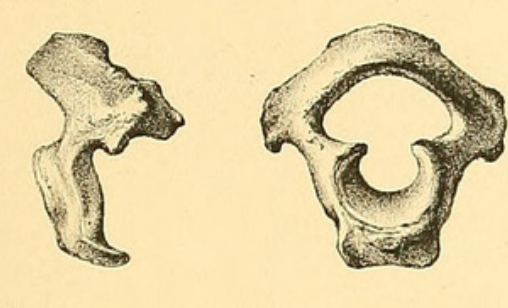

4

2

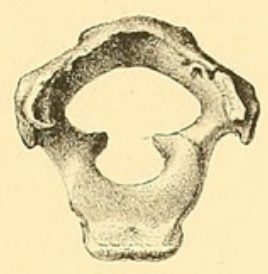

3
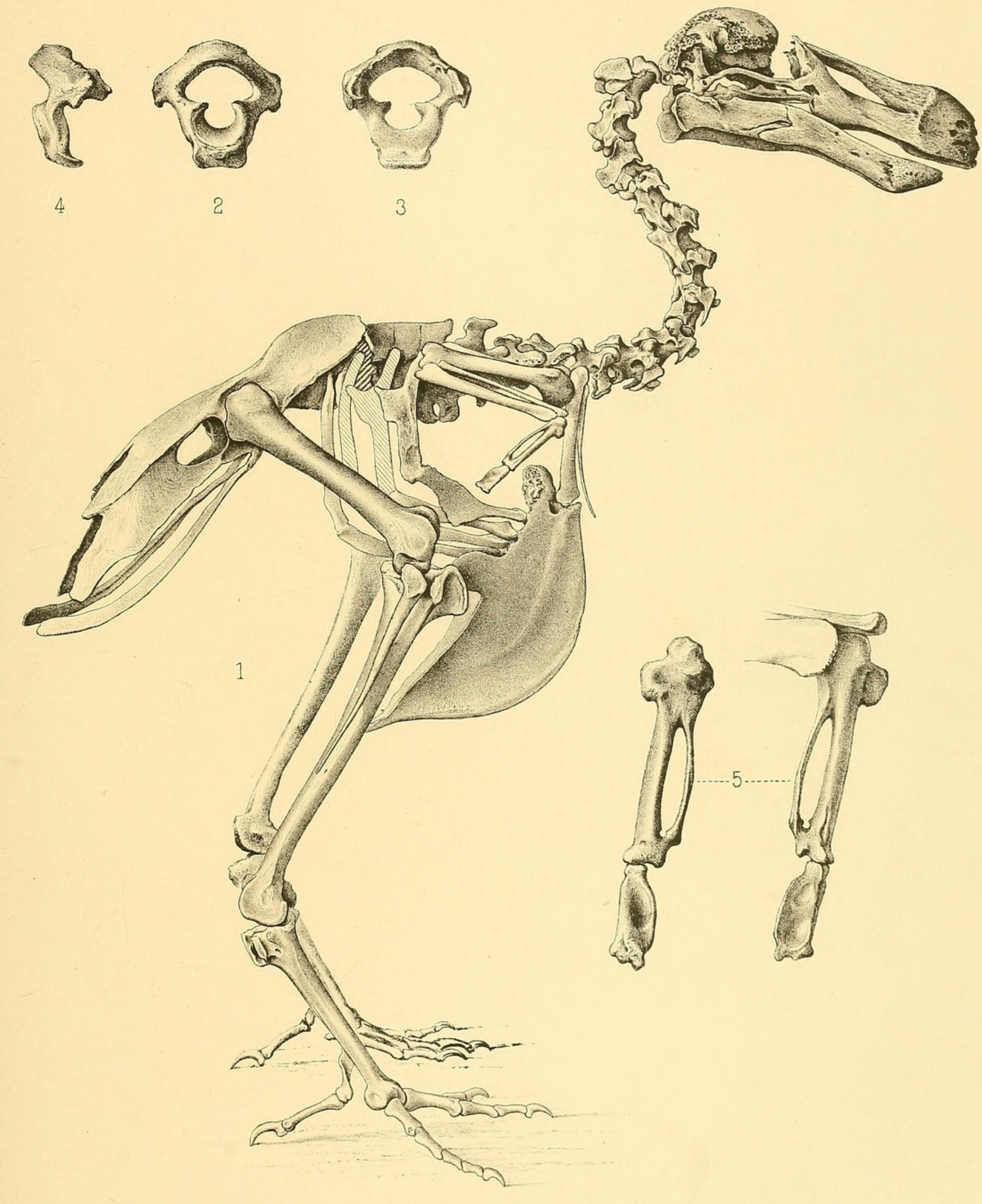

FIG. 1-5 DIDUS INEPTUS 

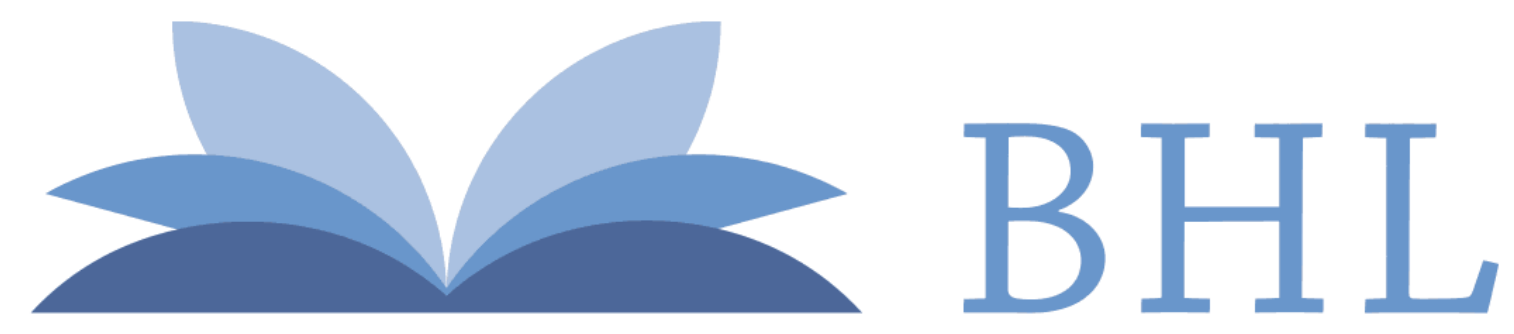

\section{Biodiversity Heritage Library}

Newton, Edward and Gadow, Hans. 1893. "IX. On additional Bones of the Dodo and other Extinct Birds of Mauritius obtained by Mr. Theodore Sauzier." Transactions of the Zoological Society of London 13, 281-302. https://doi.org/10.1111/j.1469-7998.1893.tb00001.x.

View This Item Online: https://www.biodiversitylibrary.org/item/101603

DOI: https://doi.org/10.1111/j.1469-7998.1893.tb00001.x

Permalink: https://www.biodiversitylibrary.org/partpdf/119070

\section{Holding Institution}

Smithsonian Libraries

\section{Sponsored by}

Biodiversity Heritage Library

\section{Copyright \& Reuse}

Copyright Status: Public domain. The BHL considers that this work is no longer under copyright protection.

This document was created from content at the Biodiversity Heritage Library, the world's largest open access digital library for biodiversity literature and archives. Visit BHL at https://www.biodiversitylibrary.org. 